\title{
EFFECT OF MATING ON FOLLICULAR FLUID STEROIDS IN THE RABBIT
}

\author{
E. V. YOUNGLAI \\ Department of Obstetrics and Gynecology, \\ McMaster University, Hamilton, Ontario, Canada
}

(Received 7th Fanuary 1972, accepted 8th February 1972)

A number of previous investigations have dealt with steroid levels in follicular fluid of the mare (Short, 1961; van Rensburg \& van Niekerk, 1968; YoungLai, 1971), the cow (Short, 1962; Lunaas, 1964) and human (Abraham, Odell, Edwards \& Purdy, 1970). With the development of highly sensitive methods for the detection of steroids in small amounts of biological material, it was of interest to determine whether steroids could be detected in follicular fluid of a reflex ovulator such as the rabbit. It was felt that by adopting this approach more direct evidence would be obtained for the synthesis and release of oestrogen by the ovarian follicle of this species.

Sexually mature, virgin, New Zealand white rabbits $(3.5$ to $5.5 \mathrm{~kg}$ ) were used. Does were mated to a fertile buck. Anaesthesia was induced with sodium pentobarbitone and a sample of carotid arterial blood was taken before removal of the ovaries. Plasma was separated and stored frozen until it was analysed. Ovaries were kept moist in ice-cold saline until needed for removal of follicular fluid when they were blotted dry. Follicles, 1 to $2 \mathrm{~mm}$ in diameter, were punctured and fluid was aspirated from individual follicles into preweighed $10-\mu 1$ capillary tubes. The tubes were then washed into $12 \times 75 \mathrm{~mm}$

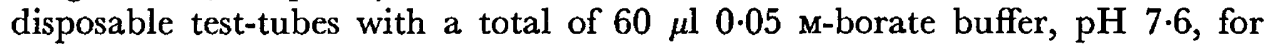
progestin determination or $60 \mu \mathrm{l}$ phosphate buffer, $\mathrm{pH} 8 \cdot 0$, for radioimmunoassay of immunoreactive oestrogen. No extraction or purification was carried .out and determinations were performed directly on the samples.

The weight range of the follicular fluid samples was 0.192 to $5.372 \mathrm{mg}$, mean \pm S.E.M. 1.950 \pm 0.071 . When a pool of follicular fluid obtained from a rabbit $3 \mathrm{hr}$ after mating was diluted with buffer and assayed for oestrogen, the dose-response curve was parallel to that of the standards. A similar observation was made for human follicular fluid (Abraham et al., 1970).

Progestin was measured by the protein-binding method of Johansson (1969) and oestrogen by a radioimmunoassay method similar to that of $\mathrm{Wu} \&$ Lundy (1971).

The values of immunoreactive oestrogen and progestin are shown in Table 1. It is evident from the data in this Table that there was a dramatic rise in follicular immunoreactive oestrogen $3 \mathrm{hr}$ after coitus. Follicular progestin also showed an increase, though not as pronounced as the oestrogen. By $9 \mathrm{hr}$ after coitus, steroid levels were low and the follicular fluid had become rather 
viscous. In the 12 -hr group, $50 \%$ had ovulated and some of the samples taken from these ovaries with corpora lutea may have been from atretic follicles.

When plasma samples were extracted and analysed, levels of immunoreactive oestrogen were lower than $40 \mathrm{pg} / \mathrm{ml}$ at all times. Eaton \& Hilliard (1971) have also shown that plasma obtained from rabbits by heart puncture contained less than $50 \mathrm{pg}$ oestrone, oestradiol $/ \mathrm{ml}$. The same plasma samples were also examined for progesterone. Values $3 \mathrm{hr}$ after coitus were higher, $5.90 \pm 1.24$ (S.E.M.) $\mathrm{ng} / \mathrm{ml}$ than at other periods: $2.03 \pm 0.71 \mathrm{ng} / \mathrm{ml}$ before coitus, $2.63 \pm 1.23 \mathrm{ng} / \mathrm{ml} 6 \mathrm{hr}$ after coitus and $2 \cdot 19 \pm 0.41 \mathrm{ng} / \mathrm{ml} 9 \mathrm{hr}$ after coitus. For progesterone determination, samples were extracted with distilled $\mathrm{n}$-hexane and the dried extracts were subjected to protein-binding assay. Ten samples containing progesterone in the range of 0.5 to $8 \mathrm{ng} / \mathrm{ml}$ were also extracted with diethyl ether, chromatographed on washed Whatman No. 40 ashless paper and the progesterone, which was easily separated from other steroids known to bind to corticosterone-binding globulin, was eluted and

TABLE 1

IMMUNOREACTIVE OESTROGEN AND PROGESTIN IN RABBIT FOLLICULAR FLUID BEFORE AND AFTER COPULATION

\begin{tabular}{|c|c|c|c|c|}
\hline Sexual status & No. of animals & $\begin{array}{c}\text { Wt. of ovaries } \\
(\mathrm{mg}) \\
(\text { Mean } \pm \text { S.E.M.) }\end{array}$ & $\begin{array}{c}\text { Oestrogen } \\
(\text { pg/mg fluid }) \\
(\text { Mean } \pm \text { S.E.M. })\end{array}$ & $\begin{array}{c}\text { Progestin } \\
\text { (ng/mg fluid }) \\
(\text { Mean } \pm \text { S.E.M. })\end{array}$ \\
\hline $\begin{array}{l}\text { Before coitus } \\
3 \mathrm{hr} \text { after coitus } \\
6 \mathrm{hr} \text { after coitus } \\
9 \mathrm{hr} \text { after coitus } \\
12 \mathrm{hr} \text { after coitus } \\
\text { (three ovulations) }\end{array}$ & $\begin{array}{l}9 \\
7 \\
6 \\
9 \\
6\end{array}$ & $\begin{array}{l}168 \pm 10 \cdot 9 \\
172 \pm 14 \cdot 4 \\
238 \pm 31 \cdot 7 \\
231 \pm 6 \cdot 4 \\
230 \pm 13 \cdot 7\end{array}$ & $\begin{array}{c}60 \cdot 2 \pm 4 \cdot 6(25)^{*} \\
271 \cdot 3 \pm 3 \cdot 7(19) \\
30 \cdot 3 \pm 7 \cdot 8(20) \\
<10.0(16) \\
<10.0(7)\end{array}$ & $\begin{array}{l}0.75 \pm 0.13(18) \\
1.53 \pm 0.26(10) \\
0.40 \pm 0.16(19) \\
<0.20(32) \\
<0.20(8)\end{array}$ \\
\hline
\end{tabular}

* Number of samples of follicular fluid from each group. Determinations were carried out on individual follicles.

quantified. No significant difference was observed between these values and those obtained after direct assay of the n-hexane extracts.

The data presented in Table 1 provide strong suggestive and direct evidence that the follicles of the rabbit do produce oestrogen and are complementary to the data obtained by Hilliard \& Eaton (1971), who analysed ovarian vein samples for oestrogen after mating. They observed a twofold increase in oestrogen output by the ovary within $3 \mathrm{hr}$ of coitus. This increase was attributed to the effects of LH which is known to be released within minutes of mating (Hilliard, Spies \& Sawyer, 1969). Thus, it seems that oestrogen produced by the follicles is released into the ovarian vein and some is secreted into, or trapped within, the follicle. It is of interest to note that $6 \mathrm{hr}$ after mating oestrogen in the follicular fluid had fallen. There is a very striking similarity between these data and those of Hilliard \& Eaton (1971). The combined data suggest that the effects of $\mathrm{LH}_{\mathrm{H}}$ are very short-lived. What effect oestrogen has within the follicle is difficult to determine from these studies but it is known that the follicular fluid becomes very viscous as the follicle swells. This observa- 
tion was confirmed in these studies. Mills, Davies \& Savard (1971) have also demonstrated that oestrogen synthesis in vitro by rabbit follicles is stimulated by LH.

Although progesterone has been found in rabbits' ovarian vein plasma after coitus, 10 to $20 \mu \mathrm{g} / \mathrm{ovary} / \mathrm{hr}$, no significance was attributed to these findings (Hilliard \& Eaton, 1971). The progesterone in the carotid artery could be derived from the adrenals, as in the rat (Feder, Brown-Grant \& Corker, 1971), or from peripheral conversion of $20 \alpha$-dihydroprogesterone. It is uncertain whether progesterone in the carotid artery has any rôle in ovulation.

Oestradiol antiserum was kindly provided by $\mathrm{Dr}$ B. V. Caldwell and Dr G. E. Abraham. Sincere thanks are due to $\mathrm{Mr}$ G. Valkenburg for providing animal facilities, Miss L. Finnis for typing the manuscript and Dr F. L. Johnson for his encouragement. This work was supported by the Medical Research Council of Canada MA-4192.

\section{REFERENCES}

Abraham, G. E., Odell, W. D., Edwards, R. \& Purdy, J. M. (1970) Solid-phase radioimmunoassay of estrogens in biological fluids. Acta endocr., Copenh. Suppl. 147, 332.

Eaton, L. W. \& Hilliard, J. (1971) Estradiol-17 $\beta$, progesterone and 20 $\alpha$-hydroxypregn-4-en-3-one in rabbit ovarian venous plasma. I. Steroid secretion from paired ovaries with and without corpora lutea; effect of LH. Endocrinology, 89, 105.

Feder, H. H., Brown-Grant, K. \& Corker, C. S. (1971) Pre-ovulatory progesterone, the adrenal cortex and the critical period for luteinizing hormone release in rats. F. Endocr. 50, 29.

HilliaRd, J. \& Eaton, L. M. (1971) Estradiol-17 $\beta$, progesterone and 20 $\alpha$-hydroxypregn-4-en-3-one in rabbit ovarian venous plasma. II. From mating through implantation. Endocrinology, 89, 522.

Hilliard, J., SPIEs, H. G. \& SAWYER, C. H. (1969) Hormonal factors regulating ovarian cholesterol mobilization and progestin secretion in intact and hypophysectomized rabbits. In: The Gonads, Chap. 3. AppletonCentury-Crofts, New York.

Johannson, E. D. B. (1969) Plasma levels of progesterone in pregnancy measured by a rapid competitive protein binding technique. Acta endocr., Copenh. 61, 607.

LunaAs, T. (1964) Distribution of oestrone and oestradiol in the bovine ovary. Acta vet. scand. 5, 35.

Mills, T. M., Davies, P. J. A. \& SAvard, K. (1971) Stimulation of oestrogen synthesis in rabbit follicles by luteinizing hormone. Endocrinology, 88, 857.

SHORT, R. V. (1961) Steroid concentrations in the follicular fluid of mares at various stages of the reproductive cycle. F. Endocr. 22, 153.

SHORT, R. V. (1962) Steroid concentrations in normal follicular fluid and ovarian cyst fluid from cows. F. Reprod. Fert. 4, 27.

van RensburG, S.J. \& van Niekerk, C. H. (1968) Ovarian function, follicular oestradiol-17 $\beta$, and luteal progesterone and $20 \alpha$-hydroxypregn-4-en-3-one in cycling and pregnant equines. Onderspoort $\mathcal{F}$. vet. Res. 35, 301.

Wu, G. H. \& Lundy, L. E. (1971) Radioimmunoassay of plasma estrogens. Steroids, 18, 91.

YoungLaI, E. V. (1971) Steroid content of the equine ovary during the reproductive cycle. $\mathcal{7}$. Endocr. 50, 589. 